Journal of Nepal Agricultural Research Council

Vol. 7: 44-53, April 2021

ISSN: 2392-4535 (Print), 2392-4543 (Online)

DOI: https://doi.org/10.3126/jnarc.v7i1.36918

\title{
The Major Chemical Constituents of Teosinte Grown as Mono and Mixed Cropping with Legumes in different Sowing Date
}

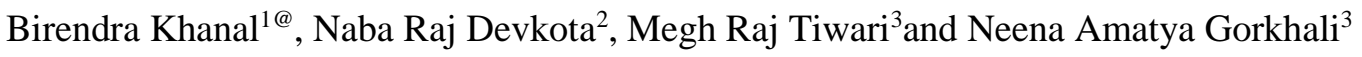 \\ ${ }^{1}$ Agriculture and Forestry University, Rampur, Chitwan, Nepal: @: birkhanal@gmail.com \\ ${ }^{2}$ Gandaki University, Kaski, Pokhara, Nepal \\ ${ }^{3}$ Directorate of Agricultural Research (Province 1), Tarahara, Sunsari, Nepal \\ ${ }^{4}$ National Animal Breeding and Genetics Research Centre, Khumaltar, Lalitpur, Nepal
}

Received 21 October, 2020, Revised 15 March, 2021, Accepted 10 April, 2021., Published 30 April, 2021

Scientific Editors: Luma Pandey and Ram Ghimire

Copyright (O) 2021 NARC. Permits unrestricted use, distribution and reproduction in any medium provided the original work is properly cited.

The authors declare that there is no conflict of interest.

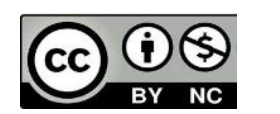

OPEN ACCESS

Licensed under the Creative Commons AttributionNonCommercial 4.0 International (CC BY-NC 4.0)

\section{ABSTRACT}

Teosinte (Euchlaena mexicana) is one of the most popular summer growing cereal fodder, yet with comparatively low level of chemical constituents. The quality of this fodder can be improved through better by cultivation management including sowing dates and mixed cropping with legume. The main objective of this study was to determine the forage quality as reflected by major chemical constituents of pure stands of teosinte and binary mixtures of teosinte with commonly available legumes under different dates of sowing. Four fodder combinations; teosinte mono crop, teosinte+ cowpea, tesosinte+ rice bean, and teosinte+ lablab bean was arranged to cultivate in three different date of sowing in the field in a Split Plot Design with 5 replications. Main plot treatments were different sowing dates and sub-plot treatments were combinations of fodder species. Dry herbage mass production, crude protein $(\mathrm{CP})$, neutral detergent fiber (NDF), acid detergent fiber (ADF), acid detergent lignin (ADL) and Ash were determined. The results showed that the significantly the highest Dry herbage and CP were obtained from fodder combination teosinte+ cowpea if sown at $18^{\text {th }}$ April, whereas the significantly highest mean values of ADF and NDF were obtained for teosinte mono fodder crop. However, the lowest average value of ADF and NDF was obtained for fodder combination teosinte with cowpea. The average value of Ash and ADL of both harvest for fodder combination and date of sowing was statistically similar $(\mathrm{p}>0.05)$. The effect of treatments interaction/combination on cumulative dry herbage was statistically high $(\mathrm{p}<0.05)$ when teosinte+ cowpea was sown at $18^{\text {th }}$ April. However, effect of treatments interaction/combination on average value of $\mathrm{CP}, \mathrm{NDF}, \mathrm{ADF}, \mathrm{ADL}$ and Ash of both harvests $(\mathrm{g} / \mathrm{kg} \mathrm{DM})$ was statistically similar ( $>0.05$ ). The results showed that mixture of teosinte with cowpea sown at $18^{\text {th }}$ April could be the best combination in terms of quantity as well as for major chemical constituents that could reflect better quality of fodder harvest.

Keywords: Fodder, chemical constituents, legume, fodder combination, fodder quality

\section{सारांश}

टियोसेन्टी (Euchlaena mexicana) गर्मीमा हुने घाँस हो । यो घाँस पौष्टिकताको हिसाबले कमजोर देखिए पनि उपयुक्त वालि उत्पादन प्रणालि मार्फत घाँसको गुणस्तरमा सुधार गर्न सकिन्छ। यस वालिमा उपयुक्त विड छर्ने समयको पहिचान गर्नु र स्थानिय स्तरमा पाइने कोशे वालि सँग मिश्रित खेति अपनाइ गुणस्तरमा सुधार ल्याउनु यस अध्ययनको मुख्य उदेश्य रहेको थियो ।यसका लागि चार थरिको घाँसहरुको संयोजन,१)टियोसेन्टी मात्र, २)टियोसेन्टी+बोडी, ३)टियोसेन्टी+सिमि र ४)टियोसेन्टीं+मस्यांग,१५ दिनको फरकमा तिन पटक लगाई $y$ रेप्लीकेसन, स्प्लिट प्लट डिजाइनमा घाँस उत्पादन गरि अनुसन्धान गरिएको थियो ।यस अनुसन्धानको हरेक संयोजनबाट उत्पादित घाँसहरुको गुणस्तर हेर्नको लागि, घाँसमा रहेको सुख्वा पदार्थ (Dry herbage mass), कच्चा प्रोटिन $(\mathrm{CP})$, न्यूट्रल डिटर्जेंट फाइबर (NDF), एसिड डिटर्जेंट फाइबर (ADF), एसिड डिटर्जेंट लिगिनन (ADL) र एसको ( Ash) मात्रा हेरिएको थियो। जस अनुसार अप्रिल १६ मा टियोसेन्टी संग बोडी रोपेको मिश्रणबाट सबैभन्दा बढी शुख्वा पदार्थ र कच्चा प्रोटिन प्राप्त गरिएको थियो । टियोसेन्टी संग बोडी रोपेको मिश्रणबाट सबै भन्दा कम न्यूट्रल डिटर्जेंट फाइबर (NDF), एसिड 
डिटर्जेंट फाइबर (ADF) पाइएको थियो । टियोसेन्टी मात्रै लगाइएको घाँसबाट कम शुख्वा पदार्थ, कच्चा प्रोटिन $(\mathrm{CP})$ र बढ़ी न्यूट्रल डिटर्जेंट फाइबर (NDF), एसिड डिटर्जेंट फाइबर ( $\mathrm{ADF}$ ) पाइएको थियो । घाँसको बिभिन्न संयोजन र रोप्ने मितिमा एस ( Ash) र एसिड डिटर्जेंट लिंग्निन (ADL) को मात्रामा खासै फरक देखिएन । यस अनुसन्धानबाट प्राप्त परिणामहरूको विश्लेषण गर्दा $१ ६$ अप्रिलमा टियोसेन्टी संग बोडी रोपेको मिश्रणबाट बढी उत्पादन र गुणस्तरीय घाँस उत्पादन भएको पाइयो।

\section{INTRODUCTION}

Quality fodder production is an important aspect of ruminant animal production. The growth of dairy sector primarily depends upon the availability of nutritious fodder. The main problem in ruminant animal production in Nepal is lack of quality fodder production in demand. There are several factors that affect the quality of fodder. Appropriate date of sowing as well as fodder combination plays a significant role in increasing fodder quality. Among the cultivated fodder crops in summer, teosinte (Euchlaena maxicana) is one of the most popular cereal fodder crop rich in energy and fair in crude protein (Upreti and Shrestha 2006, Devkota et al 2015). Cereal+legume mixtures represent complex communities of grasses and legumes that make better use of resources and have a number of positive traits in comparison to cereal monoculture. The mixing of legumes in cereals improves the protein proportion through their significant biomass contribution (Iqbal et al., 2006, Iqbal et al., 2019). The mixed sowing of legumes with cereals increases nutritional value of forage (Ahmad et al, 2007; Geren, et al., 2008), compensate the protein deficiency (Ibrahim, 2006). Forage quality can be improved by implying improved agronomic practices (Kumar, et al., 2018). Among different possibilities for increasing the quality fodder supply, teosinte sowing with locally available legumes in Nepal, for example cowpeas (Vigna unguiculata), lablab bean (Lablab purpureus), rice bean (Vigna umbellate) at appropriate date is among the most economical and effective strategies to boost nutritional quality fodder production. Limited information is available in Nepal on the effect of sowing dates and legume combination with teosinte on fodder quality parameters. Therefore, this study was done to evaluate fodder quality of teosinte grown as monoculture as well as mixtures with commonly available legumes under different dates of sowing representing flat plain area of Nepal.

\section{MATERIALS AND METHODS}

This experiment was done at Experimental site of Directorate of Agricultural Research, NARC, Lumbini Province, Khajura, Banke, during April to August, 2018. The site situated at $81^{\circ} 37^{\prime \prime}$ East longitudes and $28^{\circ} 06^{\prime \prime}$ North latitude with an altitude of 181 meters above sea level. The experiment was conducted by using a Split Plot Design with five replications. The main plot comprised of varied sowing dates and commonly available fodder legumes with teosinte in combination were set as sub-plot treatments.

The plot size of each experimental unit was $12 \mathrm{~m}^{2}$. First sowing was done in April 18, 2018, and the other sowing dates were arranged in each 15 days interval. Likewise, four fodder crop combinations used in the sub-plot treatments included: teosinte+cowpea, teopinte+rice bean, teosinte+lablab bean and sowing of teosinte as a mono crop. Plant geometry was maintained as $50 \mathrm{~cm}$ row to row for teosinte fodder/forage. Leguminous fodder/forage was sown in between the row to row spacing of teosinte. Seed rate was $40 \mathrm{~kg} / \mathrm{ha}$ for teosinte (Agrawal et al., 2012; Relwani, 1979). The fodder/forage legumes' seed rate was maintained as: cowpea (40kg/ha; Agrawal et al., 2012; Relwani, 1979); rice bean $(20 \mathrm{~kg} / \mathrm{ha}$; Khadka and Acharya, 2009) and lablab bean (40 kg/ha; Pandey and Roy, 2011). Full recommended seed rates of teosinte and half recommend seed rates of fodder/forage legumes was used. Seed ratio of teosinte: fodder/forage legumes was maintained as 100:50. Farm Yard Manure (FYM) @ 10 
t/ha and chemical fertilizer @ 60:40:0 NPK ( $\mathrm{kg} \mathrm{ha}^{-1}$ ) was applied. Full dose of FYM and phosphorus, and half dose of nitrogen was applied at the time of final field preparation, and the remaining half dose of nitrogen was applied into two split doses. First half was top dressed at one month after sowing, and the remaining half was used after first harvest.

All common agronomic practices (field preparation, irrigation, weeding) were done equally to each treatment and replications. Irrigation was applied at each 8 days interval upto certain duration (total amount of water applied for irrigation was $1183 \mathrm{~m}^{3} / \mathrm{ha}$ ). After first harvest, only one irrigation was applied than after irrigation was stopped. First irrigation was applied one day after sowing the seed.

A total of two harvests were taken. First harvest was done at 70 days after sowing and the second harvest was done at one month after first harvest. The observation teosinte plants were cut at $10 \mathrm{~cm}$ height above ground level and the legumes were maintained at $20 \mathrm{~cm}$ cutting height.

The green herbage mass was harvested from the one-meter square sampled areas from each experimental unit and weighed. The collected samples were dried in hot air oven at constant heat $\left(72^{\circ} \mathrm{C}\right.$ for $24-48$ hours) in the laboratory of Directorate of Agricultural Research, Khajura, Banke. Determination of major chemical constituents (CP, ADF, NDF, ADL and Ash) by employing proximate analysis procedures was done at National Animal Nutrition Research Centre, Khumaltar. Proximate analysis was carried out according to the procedure of Association of Official Analytical Chemist (A.O.A.C., 1990).

All the data obtained were analyzed using analysis of variance technique (ANOVA) and mean separation by using R Programming Version 4.00 (R Studio Team, 2020).

\section{RESULTS}

\section{Dry herbage mass}

The status of dry herbage mass harvested $\left(\mathrm{kg} / \mathrm{m}^{2}\right)$ under different sowing dates and fodder/forage combination is presented in Table (1). Dry herbage mass at both harvests as well as cumulative was significantly highest $(\mathrm{p}<0.001)$ if fodder/forages were sown in $18^{\text {th }}$ April compared to the other dates. Likewise at both harvests as well as cumulative, fodder combination teosinte+cowpea produced significantly the highest $(p<0.001)$ dry herbage mass and lowest from teosinte mono crop as compared to others fodder combination (Table 1 and Khanal et al., 2020). The effect of treatments interaction/combination on cumulative dry herbage was statistically higher $(\mathrm{p}<0.05)$ when teosinte+cowpea were sown at $18^{\text {th }}$ April (Table 1 and Khanal et al., 2020).

\section{Crude protein}

Crude protein contain $(\mathrm{g} / \mathrm{kg} \mathrm{DM})$ of the treatments for different harvest dates has been presented in Table (1). Amount of crude protein at first harvests was significantly highest $(\mathrm{p}<0.05)$ for fodders sown in $18^{\text {th }}$ April compared to the other dates of sowing, whereas it was statistically similar ( $>0.05)$ for all treatments in the case of second harvest.

Likewise, combination of teosinte with cowpea produced significantly highest amount of crude protein $(\mathrm{g} / \mathrm{kg} \mathrm{DM})$ at first harvest $(\mathrm{p}<0.001)$ and also at the second harvest $(\mathrm{p}<0.05)$ compared to the other combination of fodder/forages. At both the harvests, least proportions of crude protein was obtained for teosinte mono crop (Table1). 
The effects of treatments interaction/combination for amount of crude protein $(\mathrm{g} / \mathrm{kg}, \mathrm{DM})$ was statistically significant $(\mathrm{p}<0.01)$ at first harvest (Table1).

Table1. Dry herbage mass harvested $\left(\mathrm{kg} / \mathrm{m}^{2}\right)$ and crude protein production $(\mathrm{g} / \mathrm{kg} \mathrm{DM})$ at different harvest dates grown under different sowing dates and fodder combination at NARC, Khajura, Banke, 2018

\begin{tabular}{|c|c|c|c|c|c|c|}
\hline \multirow[t]{2}{*}{ Treatments } & \multicolumn{3}{|c|}{$\begin{array}{c}\text { Dry herbage mass } \\
(\mathrm{kg} / \mathrm{m} 2)\end{array}$} & \multicolumn{3}{|c|}{$\begin{array}{l}\text { Crude protein } \\
\text { (g/kg DM) }\end{array}$} \\
\hline & $\begin{array}{c}\text { First } \\
\text { harvest }\end{array}$ & $\begin{array}{l}\text { Second } \\
\text { harvest }\end{array}$ & Cumulative & $\begin{array}{c}\text { First } \\
\text { harvest }\end{array}$ & $\begin{array}{l}\text { Second } \\
\text { harvest }\end{array}$ & Average \\
\hline \multicolumn{7}{|l|}{ Sowing date (A) } \\
\hline $\begin{array}{l}\text { First sowing } \\
18^{\text {th }} \text { April (A1) }\end{array}$ & $0.941^{\mathrm{a}}$ & $0.664^{\mathrm{a}}$ & $1.605^{\mathrm{a}}$ & $135.16^{\mathrm{a}}$ & 106.70 & $120.93^{\mathrm{a}}$ \\
\hline $\begin{array}{l}\text { Second sowing } \\
3^{\text {rd }} \text { May (A2) }\end{array}$ & $0.824^{b}$ & $0.574^{\mathrm{b}}$ & $1.398^{\mathrm{b}}$ & $118.65^{\mathrm{ab}}$ & 104.79 & $111.72^{b}$ \\
\hline $\begin{array}{l}\text { Third sowing } \\
18^{\text {th }} \text { May (A3) }\end{array}$ & $0.720^{c}$ & $0.474^{\mathrm{c}}$ & $1.194^{\mathrm{c}}$ & $107.96^{\mathrm{b}}$ & 102.43 & $105.20^{\mathrm{b}}$ \\
\hline \multicolumn{7}{|l|}{ Fodder combination (B) } \\
\hline Teosinte (B1) & $0.688^{\mathrm{d}}$ & $0.533^{\mathrm{c}}$ & $1.221^{\mathrm{d}}$ & $110.94^{\mathrm{c}}$ & $95.31^{\mathrm{b}}$ & $103.12^{\mathrm{c}}$ \\
\hline Teosinte+cowpea(B2) & $0.936^{\mathrm{a}}$ & $0.609^{\mathrm{a}}$ & $1.545^{\mathrm{a}}$ & $133.89^{\mathrm{a}}$ & $110.51^{\mathrm{a}}$ & $122.20^{\mathrm{a}}$ \\
\hline Teosinte+rice bean (B3) & $0.863^{\mathrm{b}}$ & $0.579^{\mathrm{b}}$ & $1.442^{\mathrm{b}}$ & $122.07^{\mathrm{b}}$ & $105.46^{\mathrm{a}}$ & $113.76^{\mathrm{b}}$ \\
\hline Teosinte+lablab bean (B4) & $0.825^{\mathrm{c}}$ & $0.562^{b}$ & $1.387^{\mathrm{c}}$ & $115.47^{\mathrm{bc}}$ & $107.29^{\mathrm{a}}$ & $111.38^{\mathrm{b}}$ \\
\hline \multicolumn{7}{|c|}{ Interaction/combination $(\mathbf{A} \times \mathbf{B})$} \\
\hline A1B1 & $0.770^{\mathrm{d}}$ & 0.619 & $1.389^{\mathrm{de}}$ & $120.0^{\mathrm{de}}$ & 99.06 & 109.53 \\
\hline A1B2 & $1.040^{\mathrm{a}}$ & 0.700 & $1.740^{\mathrm{a}}$ & $154.75^{\mathrm{a}}$ & 115.55 & 135.15 \\
\hline A1B3 & $1.00^{\mathrm{a}}$ & 0.676 & $1.676^{\mathrm{ab}}$ & $142.37^{\mathrm{b}}$ & 105.97 & 124.17 \\
\hline A1B4 & $0.953^{\mathrm{b}}$ & 0.659 & $1.612^{\mathrm{bc}}$ & $123.51^{\mathrm{cd}}$ & 106.23 & 114.87 \\
\hline $\mathrm{A} 2 \mathrm{~B} 1$ & $0.681^{\mathrm{f}}$ & 0.517 & $1.198^{\mathrm{f}}$ & $117.19^{\text {def }}$ & 94.69 & 105.94 \\
\hline A2B2 & $0.947^{\mathrm{b}}$ & 0.608 & $1.555^{\mathrm{c}}$ & $134.87^{\mathrm{bc}}$ & 109.05 & 121.96 \\
\hline $\mathrm{A} 2 \mathrm{~B} 3$ & $0.852^{\mathrm{c}}$ & 0.596 & $1.448^{\mathrm{d}}$ & $115.17^{\text {def }}$ & 107.60 & 111.39 \\
\hline A2B4 & $0.815^{\mathrm{c}}$ & 0.577 & $1.392^{\mathrm{de}}$ & $107.37^{\mathrm{fg}}$ & 107.82 & 107.60 \\
\hline A3B1 & $0.615^{\mathrm{g}}$ & 0.463 & $1.078^{\mathrm{g}}$ & $95.62^{\mathrm{g}}$ & 92.19 & 93.91 \\
\hline A3B2 & $0.820^{\mathrm{c}}$ & 0.518 & $1.338^{\mathrm{e}}$ & $112.04^{\mathrm{def}}$ & 106.91 & 109.48 \\
\hline A3B3 & $0.737^{\mathrm{de}}$ & 0.466 & $1.203^{\mathrm{f}}$ & $108.65^{\mathrm{ef}}$ & 102.81 & 105.73 \\
\hline A3B4 & $0.707^{\mathrm{ef}}$ & 0.449 & $1.156^{\mathrm{f}}$ & $115.53^{\mathrm{def}}$ & 107.81 & 111.67 \\
\hline Mean & 0.828 & 0.571 & 1.399 & 120.59 & 104.64 & 112.62 \\
\hline \multicolumn{7}{|c|}{ Analysis of Variances (ANOVA) } \\
\hline \multicolumn{7}{|c|}{ Sowing date $(\mathrm{A})$} \\
\hline SEM & 0.064 & 0.055 & 0.12 & 7.91 & 1.24 & 4.56 \\
\hline F probability & $* * *$ & $* * *$ & $* * *$ & $*$ & NS & $*$ \\
\hline $\mathrm{LSD}_{0.05}$ & 0.06 & 0.02 & 0.06 & 18.58 & 13.41 & 8.73 \\
\hline \multicolumn{7}{|l|}{ Fodder combination (B) } \\
\hline SEM & 0.05 & 0.02 & 0.07 & 4.99 & 3.28 & 3.92 \\
\hline F probability & $* * *$ & $* * *$ & $* * *$ & $* * *$ & $*$ & $* * *$ \\
\hline $\mathrm{LSD}_{0.05}$ & 0.03 & 0.02 & 0.04 & 6.81 & 8.47 & 6.67 \\
\hline \multicolumn{7}{|c|}{ Interaction/combination (AxB) } \\
\hline SEM & 0.04 & 0.03 & 0.06 & 4.71 & 1.88 & 3.04 \\
\hline F probability & $*$ & NS & $*$ & $* *$ & NS & NS \\
\hline $\mathrm{LSD}_{0.05}$ & 0.04 & 0.04 & 0.06 & 11.79 & 14.67 & 11.55 \\
\hline
\end{tabular}

Note: $* * * * *$ and $*$ denotes significant at $0.001,0.01$ and 0.05 respectively, NS=no significant difference, SEM=standard error of the mean and LSD=least significant difference

Accordingly, at first harvest the highest amount of crude protein was obtained for fodder combination of teosinte with cowpea for the crop sown at $18^{\text {th }}$ April and the lowest amount of crude protein was produced for teosinte mono crop when sown in $18^{\text {th }}$ May. However, 
treatments interaction/combination effect on amount of crude protein yield was statistically similar ( $\mathrm{p}>0.05)$ at second harvest (Table1).

Significantly highest $(\mathrm{p}<0.05)$ average amount of crude protein of both harvests was produced if fodder/forage were sown in $18^{\text {th }}$ April, and if cowpea were sown in combination with teosinte $(\mathrm{p}<0.001)$ (Table1). The effect of treatments interaction/combination on average crude protein yield of both harvests $(\mathrm{g} / \mathrm{kg} \mathrm{DM})$ was statistically similar ( $>0.05)$ (Table1).

\section{Neutral detergent fiber (NDF)}

NDF contain (g/kg DM) for different harvests under different sowing dates and fodder/forage combination has been presented in Table (2). At both harvests, value of NDF was similar ( $p>0.05$ ) for all dates of sowing (Table 2).

Likewise, at first harvest, teosinte sown as mono crop had produced significantly the highest $(\mathrm{p}<0.01)$ amount of NDF $(\mathrm{g} / \mathrm{kg} \mathrm{DM})$. At second harvest, value of NDF remained statistically lowest $(\mathrm{p}<0.05)$ for teosinte grown in combination with cowpea.

At both harvests, the effect of treatments interaction/combination for NDF was statistically similar ( $\mathrm{p}>0.05)$ (Table 2).

The average value of NDF of two harvests was statistically similar ( $>>0.05)$ with different dates of sowing (Table 2). The significantly lowest $(\mathrm{p}<0.001)$ average value of NDF of two harvests was obtained for fodder teosinte grown in combination with cowpea (Table 2). Likewise, the effect of treatments interaction/combination was statistically similar ( $>0.05)$ for average value of NDF of two harvest (Table 2).

\section{Acid detergent fiber (ADF)}

Acid detergent fiber $(\mathrm{g} / \mathrm{kg} \mathrm{DM})$ contain at different dates for different treatments of different sowing dates and fodder/forage combination has been presented in Table (2).

At first harvest, value of ADF was statistically similar ( $p>0.05)$ to all dates of sowing (Table 2 ). At this time of measurement, ADF contain of all fodder combination was statistically significant $(\mathrm{p}<0.01)$. The lowest $\mathrm{ADF}$ value was obtained for fodder combination of teosinte with cowpea, but the value was statistically similar $(\mathrm{p}>0.05)$ with teosinte sown with lablab bean and the rice bean as well. The highest ADF value for first harvest was obtained if teosinte was sown as mono crop. Likewise, effect of treatments interaction/combination was statistically similar ( $\mathrm{p}>0.05)$ at first harvest (Table 2).

At second harvest, date of sowing had similar significant effect ( $p>0.05)$ on ADF value to all the treatments. However, at this time of measurement, ADF contain with all other fodder combination were statistically significant $(\mathrm{p}<0.001)$. The lowest ADF value was obtained for fodder combination of teosinte with cowpea, and the highest value was obtained for teosinte mono crop. Likewise effect of treatments interaction/combination was statistically significant $(\mathrm{p}<0.05)$ at second harvest (Table 2).

The average value of ADF of two harvest was statistically similar ( $p>0.05)$ with different dates of sowing (Table 2). Accordingly, average value of ADF contains of two harvest was statistically significant $(\mathrm{p}<0.001)$ for different fodder combination. The highest average value of $\mathrm{ADF}$ of two harvests was obtained for fodder teosinte sown as mono crop. On the other 
hand, effect of treatments interaction/combination was statistically similar ( $>0.05)$ for average value of ADF of two harvest (Table 2).

Table 2. NDF (g/kg DM) and ADF (g/kg DM) contained at different harvest dates grown under different sowing dates and fodder combination, at NARC, Khajura, Banke, 2018

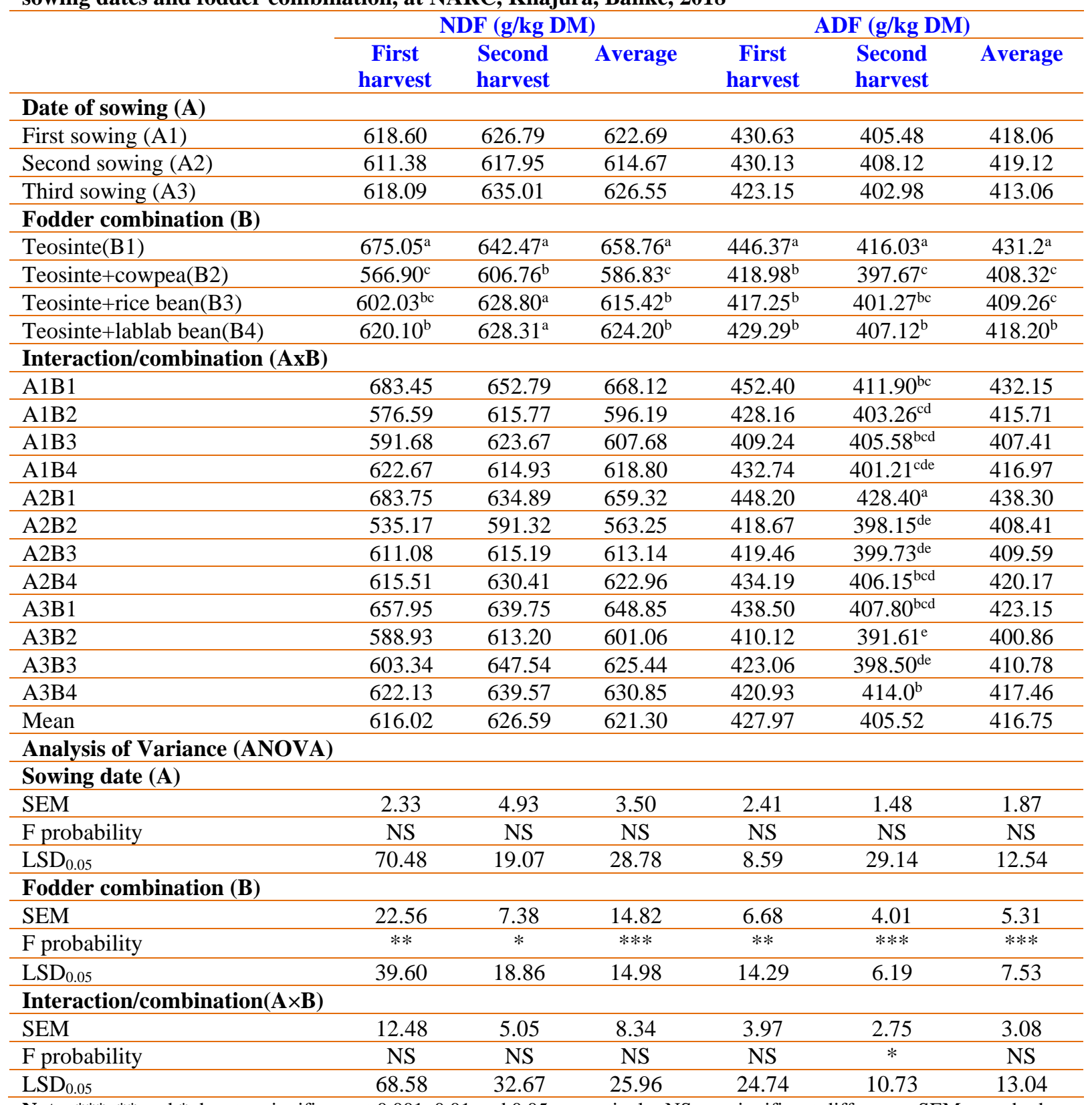

Note: $* * * * *$ and $*$ denotes significant at $0.001,0.01$ and 0.05 respectively, NS=no significant difference, SEM=standard error of the mean and LSD=least significant difference

Acid detergent lignin (ADL)

ADL contain $(\mathrm{g} / \mathrm{kg} \mathrm{DM})$ at different harvest dates grown under different sowing dates and fodder/forage combination is presented in the Table 3. At both harvests individually, as well as average value of ADL of two harvests, ADL contain was statistically similar ( $>>0.05)$ for different dates of sowing (Table 3). Similarly, fodder combinations and effect of treatments interaction/combination was also statistically similar $(\mathrm{p}>0.05)$ at both harvest as well as in the case of average value of ADF of two harvest (Table 3). 
Ash

Ash contain $(\mathrm{g} / \mathrm{kg} \mathrm{DM})$ at different harvest dates grown under different sowing dates and fodder/forage combination is presented in the Table 3. At both harvests individually, as well as average value of Ash of two harvests, Ash contain was statistically similar ( $p>0.05)$ for different dates of sowing (Table 3). Similarly, fodder combinations and effect of treatments interaction/combination was also statistically similar $(\mathrm{p}>0.05)$ at both harvests as well as in the case of average value of Ash of two harvests (Table 3).

Table 3. ADL (g/kg DM) and Ash (g/kg DM) contained at different harvest dates grown under different sowing dates and fodder combination, at NARC, Khajura, Banke, 2018

\begin{tabular}{|c|c|c|c|c|c|c|}
\hline \multirow[b]{2}{*}{ Treatments } & \multicolumn{3}{|c|}{ ADL (g/kg DM) } & \multicolumn{3}{|c|}{$\operatorname{Ash}(g / k g ~ D M)$} \\
\hline & $\begin{array}{c}\text { First } \\
\text { harvest }\end{array}$ & $\begin{array}{l}\text { Second } \\
\text { harvest }\end{array}$ & Average & $\begin{array}{c}\text { First } \\
\text { harvest }\end{array}$ & $\begin{array}{l}\text { Second } \\
\text { harvest }\end{array}$ & Average \\
\hline \multicolumn{7}{|l|}{ Sowing date (A) } \\
\hline First sowing (A1) & 52.60 & 39.27 & 45.94 & 107.0 & 101.40 & 104.20 \\
\hline Second sowing (A2) & 49.88 & 40.36 & 45.12 & 104.93 & 103.93 & 104.43 \\
\hline Third sowing (A3) & 50.58 & 39.40 & 44.99 & 104.80 & 103.83 & 104.32 \\
\hline \multicolumn{7}{|l|}{ Fodder combination (B) } \\
\hline Teosinte (B1) & 52.98 & 41.12 & 47.05 & 102.68 & 101.52 & 102.09 \\
\hline Teosinte +cowpea (B2) & 50.61 & 39.73 & 45.17 & 109.70 & 103.63 & 106.67 \\
\hline Teosinte+rice bean (B3) & 50.57 & 38.32 & 44.44 & 104.07 & 104.13 & 104.10 \\
\hline Teosinte+lablab bean(B4) & 49.92 & 39.55 & 44.73 & 105.87 & 102.96 & 104.41 \\
\hline Mean & 51.02 & 36.68 & 45.35 & 105.58 & 103.06 & 104.32 \\
\hline \multicolumn{7}{|c|}{ Analysis of Variance (ANOVA) } \\
\hline \multicolumn{7}{|l|}{ Sowing date (A) } \\
\hline SEM & 0.81 & 0.34 & 0.30 & 0.71 & 0.83 & 0.07 \\
\hline F probability & NS & NS & NS & NS & NS & NS \\
\hline $\mathrm{LSD}_{0.05}$ & 2.17 & 2.42 & 1.51 & 6.53 & 3.22 & 1.80 \\
\hline \multicolumn{7}{|l|}{ Fodder combination (B) } \\
\hline SEM & 0.67 & 0.57 & 0.59 & 1.52 & 0.57 & 0.94 \\
\hline F probability & NS & NS & NS & NS & NS & NS \\
\hline $\mathrm{LSD}_{0.05}$ & 3.63 & 2.65 & 2.26 & 7.93 & 2.30 & 4.39 \\
\hline \multicolumn{7}{|c|}{ Interaction/combination $(\mathbf{A} \times \mathbf{B})$} \\
\hline SEM & 0.60 & 0.41 & 0.41 & 1.30 & 0.64 & 0.72 \\
\hline F probability & NS & NS & $\mathrm{NS}$ & NS & NS & NS \\
\hline $\mathrm{LSD}_{0.05}$ & 6.29 & 4.58 & 3.92 & 13.74 & 3.99 & 7.60 \\
\hline
\end{tabular}

Note: $* * *, * *$ and $*$ denotes significant at $0.001,0.01$ and 0.05 respectively, NS $=$ no significant difference, SEM=standard error of the mean and LSD=least significant difference

\section{DISCUSSION}

The fodder chemical constituents (Dry herbage, CP, ADF, NDF, ADL and Ash) varied with respect to the dates of sowing and fodder combinations in the study. The reasons might be associated with the comparison of the different fodder species as they might have specific sowing dates to perform better quality parameters also due to inherent climatic requirements (Assefa and Ledin, 2001; Lauriault and Kirksey, 2004). Iqbal et al (2006) revealed that cultivating non legume with legume significantly increased total mixed green fodder and crude protein contain. Likewise, maize grown with legumes had resulted substantially increment in forage quantity and quality as compared with the maize monocultures (Javanmard et al., 2009). Ibrahim (2006) reported the highest DM yield by sowing maize and cowpea in the ratio of 75:25 and maximum crude protein was obtained from cowpea sown alone. In general, there can be a synergistic effect of cultivating cereal fodder with legumes in terms of having protein and carbohydrate accumulation that ultimately make a sense of 
certain level of herbage mass harvest. Variation in performance when cereal is grown with legumes also have been reported for maize (Geren et al., 2008). Therefore, it was well revealed that mixing of legume with cereal could well compensate the protein deficiency of cereal. Legumes supply nitrogen to cereal under mixed cropping system, so it may produce more forage yield. The higher protein contains obtained by mixed cropping of teosinte with cowpea in our research might have been obtained due to higher dry matter accumulation as well as the protein contained in the cowpea.

In other experiments revealed that mixed cropping system of legumes with maize significantly reduced $\mathrm{NDF}$ and $\mathrm{ADF}$ contain, resulting increased forage digestibility (Eskanddari, 2012; Javanmard et al., 2009). SoeHtet et al (2016) also reported that the NDF and ADF levels were higher for maize fodder as compared to intercropped fodder. Prasanthi and Venkateswaralu (2014) reported that higher crude fibre contain was observed in mono fodder maize as compared to the different mixed cropping system. Ayub et al (2004) reported that increasing the ratio of ricebean in sorghum increased crude protein and decreased crude fibre contain. Increased legume percentage on grass and legume mixture could result decreased ADF and NDF concentrations (Aasen et al., 2004). Van Soest (1996) also reported that legumes had low NDF values than cereals. Caballero et al (1995) and Haj Ayed et al (2000) also reported that with increased quantity of common vetch on companion fodder oat had increased cell contain and decreased NDF. They revealed that amount of NDF contain was decreased if increasing proportion of legume fodder on cereal fodder. Our study revealed that the lowest NDF and ADF contain was recorded from fodder combination of teosinte with cowpea. This might be due to ADF and NDF contain was observed low from cowpea as compared to others legumes. These results indicated the positive role played by cowpea when mixed with teosinte fodder in reducing ADF and NDF value in fodder combination and making better quality for fodder. NDF represents the total plant fiber or cell wall including hemicellulose, cellulose and lignin as well as ADF contains cellulose and lignin. The basic assumption is that high-quality forage has low ADF and NDF compared to low-quality forage. Rebole et al (1996) reported that the low ADF value is good quality forage for animals because of presence of less indigestible plant materials like cellulose and lignin.

Findings of this study revealed that the least effect on ADL value among different fodder combination. Many authors reported that lignin contained was observed high for legumes. Laidlaw and Teuber (2001) reported that forage legume have more lignin contain than forage grass. Lignin contain was much higher for the common vetch mono crop than for the cereal mono crops (barley and wheat) and it decreased with an increasing cereal ratio in the intercrop (Lithourgidis, et al., 2007). The cell wall of dicots contains more lignin than the cell wall of grasses, thus, legumes has more lignin (Buchananet al., 2000., Carpita and McCann, 2000). However, several authors reported the low value of ADL on mixed fodder cereal and legume. Some authors reported that plant density affected on lignin contain. Zheng et al (2017) observed that lignin contain increased on wheat with decreasing plant density. This revealed that under mixed cropping system, there is high fodder density compared to mono crop. Legume fodder helps to increase the value of lignin but high plant density on mixed cropping system resulted to reduce the lignin contain. This mutual relation of ADL contain on cereals fodder, legume fodder and mixed cropping system, may be reasons for obtaining non significant effect on ADL contain among different fodder combination.

The findings of this study revealed that Ash contain was found non-significantly different for the fodder combinations as well as for the varied date of sowing. However, mixed cropping 
produced a little higher amount of Ash as compared to mono cereal cropping. The finding was supported by many other authors. Ayub et al (2004) reported that ash contain increased with increasing proportion of rice bean in mixture with sorghum. The maximum ash was recorded when blended the seeds of sorghum, cluster bean and cowpea sown (Akhtar etal., 2013). Javanmard et al (2009) reported that mixed cropping maize with legumes increased the ash contain as compared with maize monoculture.

The findings of our study also revealed the fodder yield and quality were significantly differed for varied date of sowing. Singh et al (2017) reported that optimum date of sowing and harvesting stage could be one of the important factors for good quality fodder production. Joorabi et al (2015) also reported that delayed sowing of fodder sorghum resulted in increased CF. Comparatively low dried fodder yield of teosinte was reported for the treatments of later sowing dates compared to the treatments of earlier sowing (Devkota et al., 2017).

\section{CONCLUSION}

Fodder combination of teosinte with cowpea sown at $18^{\text {th }}$ April had produced higher Dry herbage and CP contain. Likewise, the mean values of ADF and NDF were lower in fodder combination of teosinte+cowpea and the value was more in teosinte sown as mono crop. ADL and Ash contain were similar among the fodder combinations. Thus the findings of this study well reflect the fact that fodder quality and herbage harvest both can be increased by adopting the sowing date of teosinte on $18^{\text {th }}$ April and mixing with legumes (Cowpea).

\section{ACKNOWLEDGEMENTS}

The authors are grateful to the Feed the Future, the U.S Governments of Global Hunger and Food Security Initiative for financial assistance to this study. The authors would like to offer particular thanks to the staff of Directorate of Agricultural Research, NARC, Khajura, Banke for the logistic supports. The authors would also like thank to Mr. Nabaraj Poudel, Mr. Bodh Raj Baral and Mr. Bhojan Dhakal for their supports.

\section{REFERENCES}

Aasen A, VS Baron, GW Clayton, AC Dick and DH McCartney. 2004. Swath grazing potential of spring cereals, field pea and mixtures with other species. Can. J. of Plant Sci. 84(4): 1051-1058.

Agrawal SK, RK Dixit, AK Rai, K Arvind and SK Rai. 2012. Forage crops and their management. Indian Grassland and Fodder Research Institute, Jhansi, Uttar Pradesh, India; pp. 60.

Ahmad AUH, R Ahmad, N Mahmood and A Tanveer. 2007. Performance of forage sorghum intercropped with forage legumes under different planting patterns. Pak.J. of Bot. 39(2): 431-439.

Akhtar MF, AH Ahmad, MS Ibni-Zamir, F Khalid, AU Mohsin and M Afzal. 2013. Agro-qualitative studies on forage sorghum (Sorghum bicolor L.) sown alone and in mixture with forage legumes. Pak. J. of Sci. 65(2): 179-185.

AOAC. 1990: Official methods of analysis of the association of afficiales analytical chemists. $14^{\text {th }}$ Ed. Association of Official Analytical Chemist, Washington D.C; pp. 223-225, 992-995.

Assefa $\mathrm{G}$ and I Ledin. 2001. Effect of variety, soil type and fertilizer on the establishment, growth, forage yield, quality and voluntary intake by cattle of oats and vetches cultivated in sole crops and mixtures. Anim. Feed Sci. Tech. 92: 95-111.

Ayub M, A Tanveer, MA Nadeem and SMA Shah. 2004. Studies on fodder yield and quality of sorghum grown alone and in mixture with rice bean. Pak. J. Life Soc. Sci. 2(1): 46-48.

Buchanan BB, W Gruissem and RL Jones. 2000. Biochemistry and molecular biology of plants. Am. Soc. of Plant Biologists, Maryland, USA; pp. 52-108.

Caballero R, EI Goicoechea and PJ Hernaiz. 1995. Forage yields and quality of common vetch and oat sown at varying seeding ratios and seeding rates of common vetch. Field Crop Research 41: 135-140.

Carpita N, M McCann.2000. The cell wall. In: Biochemistry and molecular biology of plants (BB Buchanan, W Gruissem and RL Jones eds). Am. Soc. Plant Physiol. Rockville; pp. 52-108 
Devkota NR, P Pokharel, LN Paudel, CR Upreti and NP Joshi. 2015. Performance of teosinte (Euchlaena Mexicana) as a promising summer forage crop with respect to location and sowing dates considering the scenario of possible climate change in Nepal. Nepalese Journal of Agricultural Science 13:131-141.

Devkota NR, RP Ghimire, DP Adhikari, CR Upreti, LN Paudel and NP Joshi. 2017. Fodder productivity of teosinte (Euchlaena Mexicana Schrad) at different sowing dates in western mid hills of Nepal. Journal of Agriculture and Forestry University 1: 129-137.

Eskanddari H. 2012. Yield and quality of forage produced in intercropping of maize (Zea mays) with cowpea (Vigna sinensis) and mungbean (Vigna radiate) as double cropped. J. Basic. Appl. Sci. Res. 2(1): 93-97

Geren H, R Avcioglo, H Soya and BKir.2008. Intercropping of corn with cowpea and bean: Biomass yield and silage quality. Afr. J. Biotechnol. 7(22): 4100-4104.

Haj-Ayed M, J Gonzalez,R Caballero and MRAlvir. 2000. Nutritive value of on-farm common vetch-oat hays. II. Ruminal degradation of dry matter and crude protein. Ann. Zootech. 49(5): 391-398.

Ibrahim M, M Rafiq, A Sultan, M Akram, MA Goheer. 2006. Green fodder yield and quality evaluation of maize and cow pea sown alone and in combination. J. Agric. Res. 44(1): 15-21.

Iqbal A, M Ayub, H Zaman and R Ahmad. 2006. Impact of nutrient management and legumes association on agro-qualitative traits of maize forage. Pak. J. Bot. 38(4):1079-1084.

Iqbal MA, A Hamid, T Ahmad, MH Siddiquil, I Hussain, S Ali, A Ali, Z Ahmad. 2019. Forage sorghumlegumes intercropping: Effect on growth, yields, nutritional quality and economic returns. Bragantia Campinas 78(1):82-95

Javanmard A, A Dabbagh, N Mohammadi, J Aziz, MV Mohammad and J Hossein. 2009. Forage yield and quality in intercropping of maize with different legumes as double cropped. J. Food Agric. Environ. 7(1): 163-166.

Joorabi S, N Akbari, MR Chaichi and K Azizi. 2015. Effect of sowing date and nitrogen fertilizer on sorghum var. speed feed) forage production in a summer intercropping system. Agron. Res. Moldavia 48(3): 63-72.

Khadka K and BD Acharya. 2009. Cultivation practices of Rice bean. Local Initiatives for Biodiversity, Research and Development (LI-BIRD), Pokhara, Nepal.

Khanal B, NR Devkota, MR Tiwari and NA Gorkhali. 2020. Maximizing fodder yield of teosinte (Euchlaena mexicana) through sowing dates and mixed fodder cropping management. Journal of Agriculture and Forestry University 4: 269-278.

Kumar R, D Kumar, C Datt, G Makarana, MR Yadav and BI Meel. 2018. Forage yield and nutritional characteristics of cultivated fodders as affected by agronomic interventions: A Review. Indian J.Anim. Nutrition 35(4): 373-385.

Laidlaw AS and N Teuber. 2001. Temperate forage grass-legume mixtures: Advances and perspectives. Proc. of the $19^{\text {th }}$ International Grassland Congress, February 11-21, 2001, Sao Paulo, Brazil; pp. 85-92.

Lauriault LM and RE Kirksey. 2004. Yield and nutritive value of irrigated winter cereal forage grass-legume intercrops in the southern high plain, USA. Agron. J. 96(2): 352-358.

Lithourgidis AS, KV Dhima, IB Vasilakoglou, AC Dordas, and MD Yiakoulaki. 2007. Sustainable production of barley and wheat by intercropping common vetch. Agronomy for Sustainable Dev. 27 (2): 95-99.

Pandey KC and AK Roy. 2011. Forage crops varieties. I.G.F.R.I Jhansi (India); pp. 69.

Prasanthi K and B Venkateswaralu. 2014. Fodder quality in fodder maize-legume intercropping systems. Journal of Tropical Agriculture 52(1): 86-89.

R Studio Team. 2020. R Studio: Integrated development for R. R Studio, PBC, Boston, MA.

Rebole A, J Trevino and R Caballero R .1996. Chemical change associated with the field Effect of mixed intercropping of clover on forage yield and quality 65 drying of oat forage. Field Crops Res. 47:221-226.

Relwani, LL. 1979. Fodder crops and Grasses. (LL Relwani eds). I.C.A.R publication; pp. 12-22.

Singh M, A Chauhan, R Kumar, D Joshi, P Soni and V Meena. 2017. Dual purpose barley as affected by date of sowing, varieties and stage of harvesting-A review. Agricultural Reviews 38 (2): 159-164.

SoeHtet MN, P Yaqin, XY Dong, RN Soomro and H Jiangbo. 2016. Effect of Intercropping Maize with Soybean (Glycine max L.) on green forage yield, and quality evaluation. J. Agric. Vet. Sci. 9(12): 59-63

Upreti CR and BK Shrestha. 2006. Nutrient contents of foods and fodder in Nepal. Kathmandu: Nepal Agricultural Research Council; pp.139.

Van Soest PJ. 1996. Allometry and ecology of feeding behavior and digestive capacity in herbivores: A Review. Zoo Biology 15: 455 - 479.

Zheng M, J Chen, Y Shi, Y Li, Y Yin, D Yang, Y Luo, D Pang, X Xu, W Li, J Ni, Y Wang, Z Wang and Y Li. 2017. Manipulation of lignin metabolism by plant densities and its relationship with lodging resistance in wheat. Sci.Rep. 7: 41805. https://doi.org/10.1038/srep41805

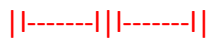

